\title{
Brazilian avian metapneumovirus subtypes A and B: experimental infection of broilers and evaluation of vaccine efficacy ${ }^{1}$
}

\author{
Márcia B. dos Santos ${ }^{2}$, Matheus C. Martini², Helena L. Ferreira ${ }^{3}$, Luciana H.A. da Silva ${ }^{2}$, \\ Paulo A. Fellipe ${ }^{2}$, Fernando R. Spilki ${ }^{4}$ and Clarice W. Arns ${ }^{2 *}$
}

\begin{abstract}
Santos M.B., Martini M.C., Ferreira H.L., Silva L.H.A., Fellipe P.A., Spilki F.R. \& Arns C.W. 2012. Brazilian avian metapneumovirus subtypes A and B: experimental infection of broilers and evaluation of vaccine efficacy. Pesquisa Veterinária Brasileira 32(12):1257-1262. Laboratório de Virologia, Instituto de Biologia, Universidade Estadual de Campinas, Rua Monteiro Lobato s/n, Cx. Postal 6109, Campinas, SP 13083-970, Brazil. E-mail: arns@unicamp.br

Avian metapneumovirus (aMPV) is a respiratory pathogen associated with the swollen head syndrome (SHS) in chickens. In Brazil, live aMPV vaccines are currently used, but subtypes A and, mainly subtype B (aMPV/A and aMPV/B) are still circulating. This study was conducted to characterize two Brazilian aMPV isolates (A and B subtypes) of chicken origin. A challenge trial to explore the replication ability of the Brazilian subtypes A and B in chickens was performed. Subsequently, virological protection provided from an aMPV/B vaccine against the same isolates was analyzed. Upon challenge experiment, it was shown by virus isolation and real time PCR that aMPV/B could be detected longer and in higher amounts than aMPV/A. For the protection study, 18 one-day-old chicks were vaccinated and challenged at 21 days of age. Using virus isolation and real time PCR, no aMPV/A was detected in the vaccinated chickens, whereas one vaccinated chicken challenged with the aMPV/B isolate was positive. The results showed that aMPV/B vaccine provided a complete heterologous virological protection, although homologous protection was not complete in one chicken. Although only one aMPV/B positive chicken was detected after homologous vaccination, replication in vaccinated animals might allow the emergence of escape mutants.
\end{abstract}

INDEX TERMS: Avian metapneumovirus, in vivo replication, vaccine protection.

RESUMO.- [Metapneumovirus aviário subtipos A e B brasileiros: infecção experimental em frangos de corte e eficácia vacinal.] 0 Metapneumovírus aviário (aMPV) é um patógeno respiratório associado à síndrome da cabeça inchada (SHS) em galinhas. Apesar de vacinas vivas contra o aMPV serem utilizadas no Brasil, os subtipos A e B (aMPV/A e aMPV/B) são ainda encontrados no país, com

\footnotetext{
${ }^{1}$ Received on May 3, 2012.

Accepted for publication on September 24, 2012.

${ }^{2}$ Laboratório de Virologia, Instituto de Biologia, Universidade Estadual de Campinas (Unicamp), Rua Monteiro Lobato s/n, Cx. Postal 6109, Campinas, SP 13083-970, Brazil. *Corresponding author: arns@unicamp.br or clarns@gmail.com

${ }^{3}$ Departamento de Ciência Animal, Escola de Ciência Animal e Engenharia de Alimentos, Universidade de São Paulo (USP), Av. Duque de Caxias Norte, 225, Pirassununga, SP 13635-900, Brazil.

${ }^{4}$ Universidade Feevale, Av. Dr. Maurício Cardoso 510, Novo Hamburgo, RS 93510-250, Brazil.
}

predominância do subtipo B. Este estudo foi conduzido com o intuito de estudar dois isolados brasileiros de aMPV (subtipos A e B) isolados de frango. Para isto, um desafio experimental em frangos foi conduzido com o intuito de explorar a capacidade de replicação dos subtipos A e B Brasileiros. Posteriormente, a protecção virológica conferida por uma vacina do subtipo B em pintos foi realizada com os mesmos isolados. Após o desafio experimental demonstrou-se, por isolamento viral e PCR em tempo real, que o isolado do subtipo B replicou por maior período de tempo e em quantidades maiores, em comparação com o subtipo A. Para o estudo de proteção, 18 pintos de um dia de idade foram vacinados e desafiados aos 21 dias. Usando isolamento viral e PCR em tempo real, em nenhuma ave vacinada e desafiada com aMPV/A foi detectado o vírus, ao passo que uma ave vacinada e desafiada com o aMPV/B foi positiva. Os resultados mostraram que a vacina do subtipo B forneceu protecção heteróloga completa, embora a protecção homóloga 
não tenha sido conferida em uma ave. Apesar de o aMPV/B ter sido detectado em apenas um frango após vacinação homóloga, a replicação viral em aves vacinadas pode resultar em emergência de mutantes de escape.

TERMOS DE INDEXAÇÃO: Metapneumovirus aviário, replicação in vivo, proteção vacinal.

\section{INTRODUCTION}

Avian metapneumovirus (aMPV) is classified as a member of the Metapneumovirus genus within the family Paramyxoviridae (Njenga et al. 2003). The virus is able to replicate in the respiratory tract, especially the upper tissues, resulting in an acute respiratory disease in turkeys and chickens with significant economic losses, especially if the infection is associated with secondary pathogens (Jirjis et al. 2002, Gough et al. 2008). In broilers, aMPV is involved, among other agents, in the swollen head syndrome (SHS) (Cook et al. 1995) and is likely to play a role in pathogenesis of testicular disease (Villarreal et al. 2007).

Based on molecular analysis of the genome, aMPV can be classified into four subtypes: A, B, C and D, (Juhasz et al. 1994, Toquin et al. 2000, Dar et al. 2001, Alvarez et al. 2003) and is circulating in many countries. aMPV subtypes $A$ and $B$ (aMPV/A and aMPV/B) are more widespread in the world, whereas subtype $C$ is found in the United States and in domestic duck breeders in France (Toquin et al. 2006) and subtype D was once reported in France (Cook et al. 2000, Njenga et al. 2003). In Brazil, where a high density of poultry farms exists, studies on chicken and turkey flocks demonstrated a high prevalence of aMPV/A and aMPV/B infection (Chacón et al. 2007, D'Arce et al. 2005), with a higher number of aMPV/B circulating in the last years (Chacón et al. 2011, Villarreal et al. 2009). Field evidences worldwide also point to the higher circulation of subtype B viruses over subtype A for reasons not well understood (Banet-Noach et al. 2005, Jones 2010).

Despite the evidence of excellent cross protection between aMPV/A and aMPV/B (Cook et al. 1995, Eterradossi et al. 1995), disease in vaccinated flocks has still been reported in Brazil and in other countries with high poultry density (Banet-Noach et al. 2009, Cecchinato et al. 2009, Catelli et al. 2010, Chacón et al. 2011). In some cases, disease may have been caused by infection with the subtype not included in the vaccine (Banet-Noach et al. 2005, 2009, Cecchinato et al. 2009). In other cases, it could have been caused by genetic differences between the field and vaccine strains, which may be sufficient to allow immune evasion (Banet-Noach et al. 2009, Catelli et al. 2010) or by inadequate vaccine administration leading to reversion to virulence (Catelli et al. 2006, Ricchizzi et al. 2009).

This study was conducted to better understand the behavior of two Brazilian aMPV isolates in chicks. aMPV/A and $\mathrm{aMPV} / \mathrm{B}$ of chicken origin were selected for this purpose. At first, a challenge trial was performed to explore the replication ability of the Brazilian isolates, under controlled experimental conditions. Subsequently, the protective response induced by a commercially available aMPV/B vaccine was investigated using both aMPV/A and aMPV/B isolates as challenge viruses.

\section{MATERIALS AND METHODS}

\section{Viruses}

Two Brazilian aMPV isolates were used in these experiments. The strains designated as Chicken/A/BR/775/06 and Chicken/ B/BR/877/08 were confirmed by RT-nested PCR (Naylor et al. 1997) to belong to subtype $A$ and $B$, respectively. Both strains were isolated from broiler chicks flocks after serial blind passages in Chicken Embryo Related (CER) cells (Coswig et al. 2010) and a RT-nested PCR was used to confirm virus presence. The strains Chicken/A/BR/775/06 and Chicken/B/BR/877/08 were titrated in CER cells, end points were calculated by the method of Reed and Muench (1938), and expressed in 50\% of tissue cell infectious doses per $\mathrm{mL}\left(\mathrm{TCID}_{50} / \mathrm{mL}\right)$.

\section{Vaccine}

The chicks were inoculated with a commercial aMPV/B vaccine, at a titre of $3.8 \log _{10} \mathrm{TCID}_{50} /{ }_{\mathrm{mL}}$, by the oculonasal (o.n.) route at the dose recommended by the manufacturer.

\section{Experimental design}

In vivo replication study. At two weeks of age, two groups of 25 chicks were divided and inoculated by the o.n. route with $0.2 \mathrm{ml}$ of aMPV/A or aMPV/B field strains at $4.3 \log _{10} \mathrm{TCID}_{50} / \mathrm{mL}$. A non-challenged control group was included. All groups were maintained in separate isolation units. After inoculation, broilers were observed for clinical signs daily up to 14 days post infection (d.p.i.). At 3, 5, 7, 10 and 14 d.p.i. five birds from each group were euthanized. Sinusal swabs and tissue scraped from trachea were collected individually and suspended in $1 \mathrm{ml}$ of E-MEM containing $1 \mathrm{mg} / \mathrm{mL}$ enrofloxacin. After shaking, samples were centrifuged for $5 \mathrm{~min}$ at $3500 \mathrm{~g}$ to sediment the cellular debris. The supernatants were harvested and stored at $-80^{\circ} \mathrm{C}$ until used.

Protection study. Two groups of 21 birds were either vaccinated (one-day-old) or remained as controls. At the day of vaccination and at weekly intervals during three weeks, blood samples were collected from ten chicks as an indicator of vaccine immunogenicity. At 21 days of age, 18 birds of each group were subdivided in two groups and challenged with $0.2 \mathrm{ml}$ of aMPV/A or aMPV/B field strains at $4.3 \log _{10} \mathrm{TCID}_{50} / \mathrm{mL}$ by the o.n. route. Samples of the three remaining birds of each group (vaccinated and non-vaccinated), before the virological exposure, were collected to determine whether vaccine virus could be detected 21 days post vaccination (d.p.v.), these birds were then euthanized. A non-vaccinated and non-challenged control group with nine birds was included in the experiment. All groups were maintained in separate isolation units. After inoculation, broilers were observed for clinical signs daily up to 7 d.p.c. At 3, 5 and 7 d.p.c. three birds from each group were euthanized. The sinusal and tissue tracheal samples were individually collected for virological examination and processed as the first experiment.

All animal studies were performed under supervision of the bioethics committee of the UNICAMP (protocol number 1716-2), following standard national guidelines.

\section{Viral shedding by real time RT-PCR and virus titration}

Sinusal swabs and tissue scraped from trachea were collected individually from both in vivo experiments. RNA was extracted from each sample and cDNA prepared, followed by real time RT-PCR based on amplification of the $\mathrm{F}$ (fusion) protein gene of aMPV/A (Ferreira et al. 2009) or B (Santos 2010). Threshold cycle values (Ct) were used, as Ct indicates the PCR cycle number at which the amount of amplified target reaches a fixed threshold. 


\section{Virus titration}

Individual samples from both in vivo experiments were inoculated in CER cells. When the viral cytopathic effect (CPE) was observed, the original samples were titrated in CER cells. Serial 10-fold dilutions were inoculated in CER 96-well plates following standard procedures. Titres were calculated by the Reed and Muench (1938) method and expressed as the $\log _{10}$ tissue culture infective dose per $\mathrm{mL}\left(\mathrm{TCID}_{50} / \mathrm{mL}\right)$.

\section{Serum neutralization tess}

The sera were assayed for the presence of antibodies by the serum neutralization (SN) test. All SN titres $>3(\log 2)$ were considered as positive.

\section{Statistical analysis}

In the phenotypic characterization study, viral titre and Ct values obtained from groups challenged with aMPV/A or aMPV/B were analyzed using the paired and unpaired T test (Graph Pad Prism 5.0 software). Results are given as mean values $( \pm \mathrm{SE})$ and $p$ values less than 0.05 were considered statistically different.

\section{RESULTS}

Virus shedding by chickens inoculated with aMPV/A and $\mathbf{a M P V} / \mathrm{B}$

No clinical signs were observed in the control group or in chicks inoculated with aMPV/A. In animals inoculated with the aMPV/B field strain, a clear nasal discharge was seen mainly at 5 and 7 d.p.i. when the nares were squeezed gently.

Chicks in groups infected with aMPV/A or aMPV/B had different viral shedding patterns: aMPV/B could be detected longer and in higher quantities by real time RT-PCR compared to aMPV/A strain. aMPV/A RNA was only detected at 3, 5 and 7 d.p.i. (Fig.1A) whereas aMPV/B was detected at all five time points (Fig.1B). The highest RNA detection was obtained in sinus for both subtypes, at 5 d.p.i. for aMPV/A (Ct: 33.21) and 3 d.p.i. for aMPV/B (Ct: 27.18). When mean $\mathrm{Ct}$ value of sinusal and tracheal samples were compared, those in the aMPV/B challenged group at 3, 5, and 7 d.p.i. were significantly higher $(P$ value $\leq 0.05)$ than those in the challenged group with aMPV/A. No aMPV RNA was detected in the non-challenged control group.

Virus was recovered from the trachea and sinus at all days p.i. for aMPV/B challenged group (Table I). The highest virus titre in tracheal samples was observed at $7 \mathrm{~d}$.p.i. $\left(2.3 \log _{10} \mathrm{TCID}_{50} / \mathrm{mL}\right)$ and in sinusal samples at 3 and 5 d.p.i. (2.7 $\log _{10} \mathrm{TCID}_{50} / \mathrm{mL}$ ). aMPV/A was detected only in sinusal samples at 3 and 5 d.p.i. with titre mean of 1.7 and $1.9 \log _{10}$ $\mathrm{TCID}_{50} / \mathrm{mL}$, respectively. Statistically significant difference

Table 1. Mean titres in trachea and sinuses of chickens inoculated with aMPV/A or aMPV/B

\begin{tabular}{cccccc}
\hline \multirow{2}{*}{$\begin{array}{c}\text { Days post } \\
\text { inoculation }\end{array}$} & \multicolumn{2}{c}{ Trachea } & & \multicolumn{2}{c}{ Sinus } \\
\cline { 2 - 3 } \cline { 5 - 6 } & $\mathrm{A}$ & $\mathrm{B}$ & & $\mathrm{A}$ & $\mathrm{B}$ \\
\hline 3 & - & $1.7^{\mathrm{a}}$ & & 1.7 & 2.7 \\
5 & - & 1.8 & & 1.9 & 2.7 \\
7 & - & 2.3 & & - & 1.7 \\
10 & - & 1.9 & & - & 1.7 \\
14 & - & 1.7 & & - & 1.7
\end{tabular}

Titres are expressed in $\log _{10} \mathrm{TCID}_{50} / \mathrm{mL}$. a Values are mean of five birds.
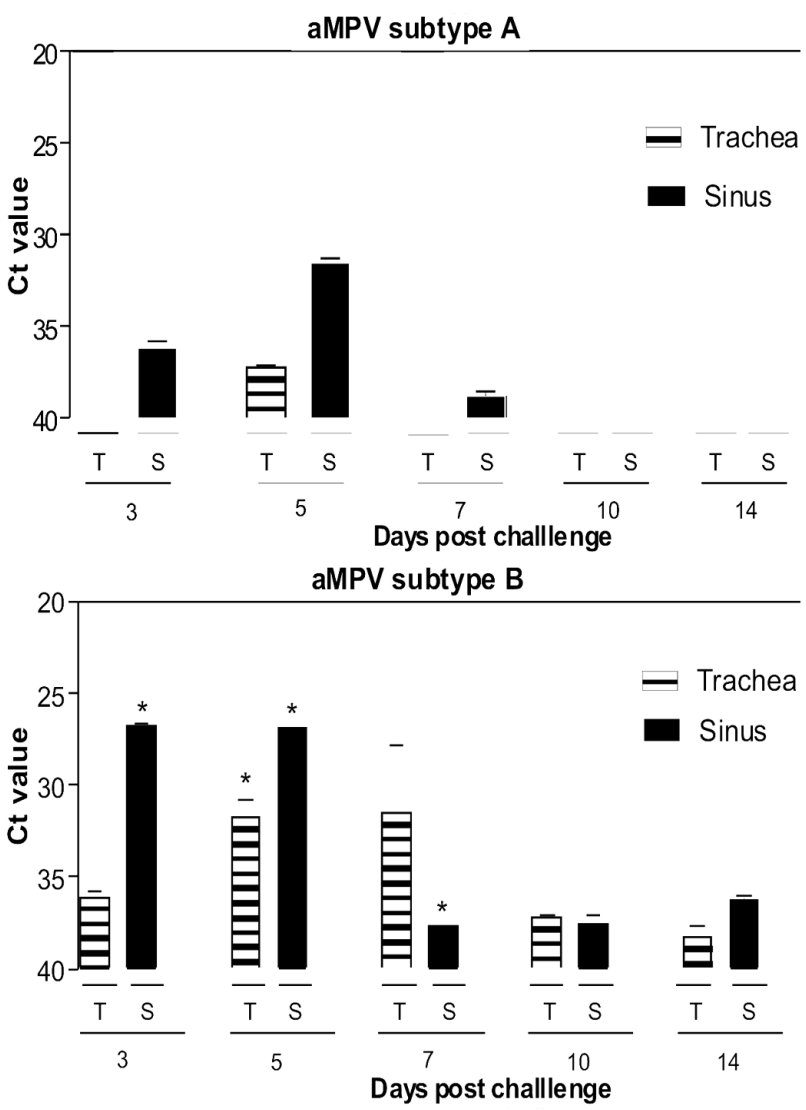

Fig.1. RNA virus detection by real time RT-PCR from trachea and sinuses of birds inoculated with field aMPV/A or aMPV/B at 3, 5, 7, 10 and 14 d.p.i. Asterisk $\left({ }^{*}\right)$ means $\mathrm{Ct}$ number of the aMPV/A challenged group $(\mathrm{A})$ is significantly $(\mathrm{P}<0.05)$ lower than the corresponding value of the aMPV/B challenged group (B).

$(P$ value $\leq 0.05)$ between aMPV/A and aMPV/B titres was seen in sinusal samples obtained at 3 d.p.i. As expected, no infectious virus was recovered from the control group.

As described above, aMPV/B replication could be observed longer and in larger amount compared to the aMPV/A in inoculated chickens.

\section{Protection study}

Serological response. All pre-vaccination sera were negative for aMPV antibodies by the SN test. At 14 and 21 days post vaccination (d.p.v.) all vaccinated birds were positive for aMPV antibodies. The neutralizing antibodies titres reached their maximal level with titres around $8 \log _{2}$ at 21 d.p.v. (Fig.2).

Virological and clinical findings after challenge. No clinical signs were observed in the non-vaccinated and non-challenged (control) or either of the vaccinated-challenged groups (B/A and B/B groups) and in non-vaccinated chicks challenged with aMPV/A strain (-/A group). In the non-vaccinated chicks challenged with aMPV/B (-/B group) at 21 days of age, a clear nasal discharge was seen in individuals mainly at 5 and 7 d.p.c. when the nares were squeezed gently.

The mean viral detection by real-time RT-PCR or virus isolation for the vaccinated and unvaccinated groups is 


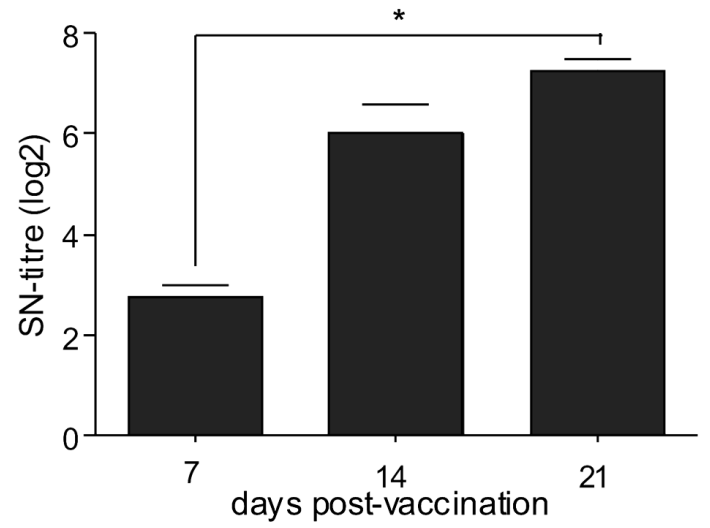

Fig.2. Mean serum neutralization titres of chickens after vaccination with aMPV/B. Asterisk $\left(^{*}\right)$ means SN titre are significantly $(\mathrm{P}<0.05)$ different.

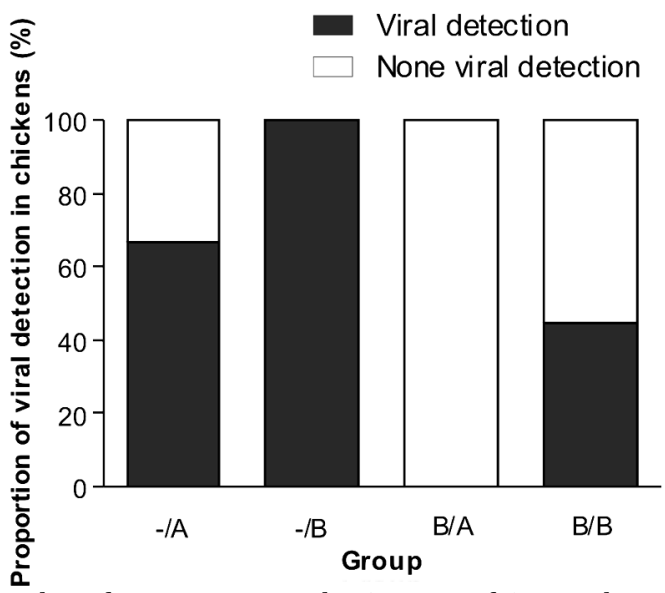

Fig.3. Results of protection study. Groups of 9 one-day old chickens were vaccinated with commercial aMPV/B vaccine. After 21 days of vaccination, they were challenged with either homologous (group B/B) or heterologous subtype field virus (group B/A). Unvaccinated chickens were challenged with one or the other virus (-/B and -/A groups). The figure shows the percentage of detected positive birds for aMPV by real time RT-PCR or virus titration in each group at all times in d.p.c.

shown in fig. 3. No virus was detected in chicks which were not vaccinated or challenged. Also, no aMPV/B vaccine could be detected in vaccinated and non-challenged chicks at 21 d.p.v., asserting that aMPV/B detected after 21 d.p.v. were of field origin. In -/A group, viral RNA was detected at 3 and 5 d.p.c., infectious virus was recovered at 5 d.p.c. from trachea and sinus of all birds and at 3 d.p.c. in sinusal samples. aMPV/B strain was detected in -/B group, except for the tracheal samples collected at 7 d.p.c. The highest virus titre and lowest $\mathrm{Ct}$ value were observed at 5 d.p.c. from sinusal samples of both -/A group (2.8 $\log _{10} \mathrm{TCID}_{50} / \mathrm{mL}$, Ct: $31.43)$ and -/B group (4.0 $\log _{10} \mathrm{TCID}_{50} / \mathrm{mL}$, Ct: 27.92$)$. In B/B group, viral RNA was detected in 4 out of 9 birds at 3 , 5 or 7 d.p.c. Only one bird in B/B group yielded infectious virus: 2.5 and $2.8 \log _{10} \mathrm{TCID}_{50} / \mathrm{mL}$ in sinusal and tracheal samples, respectively. In B/A group, no virus was detected by real time RT-PCR or virus titration. Table 2 shows the recovery of virus from the challenged birds which were initially vaccinated or not.
Table 2. Mean titres in trachea and sinuses of chickens vaccinated with a commercial $\mathrm{aMPV} / \mathrm{B}$ vaccine and challenges with field aMPV/A and aMPV/B isolates

\begin{tabular}{|c|c|c|c|c|c|c|c|}
\hline \multicolumn{8}{|c|}{ Sinus } \\
\hline \multirow[t]{2}{*}{ Vaccine } & \multirow[t]{2}{*}{ Challenge } & \multicolumn{2}{|r|}{$3 d p c$} & \multicolumn{2}{|c|}{$5 \mathrm{dpc}$} & \multicolumn{2}{|c|}{$7 \mathrm{dpc}$} \\
\hline & & Titre & $\mathrm{Ct}$ & Titre & $\mathrm{Ct}$ & Titre & $\mathrm{Ct}$ \\
\hline B & A & - & - & - & - & - & - \\
\hline B & B & $-/-/ 2.5^{b}$ & $-/-/ 31.41$ & - & - & - & $-/-/>39$ \\
\hline None & A & $<2.3^{\mathrm{a}}$ & 38.64 & 2.8 & 31.43 & - & - \\
\hline None & B & 2.5 & 33.07 & 4.0 & 27.92 & 2.3 & 38.79 \\
\hline & & & Trachea & & & & \\
\hline B & A & - & - & - & - & - & - \\
\hline $\mathrm{B}$ & $\mathrm{B}$ & $-/-/ 2.8$ & $-/>39 / 29.45$ & - & $-/-/>39$ & - & $-/-/ 29.98$ \\
\hline None & A & - & $-/-/>39$ & 2.5 & 36.77 & - & - \\
\hline None & $\mathrm{B}$ & 2.7 & 31.91 & 3.0 & 30.67 & - & 32.56 \\
\hline
\end{tabular}

Titres are expressed in $\log _{10} \mathrm{TCID}_{50} / \mathrm{mL}^{\text {a }}$ Values are means of tree birds, except when only some of the samples yielded virus, in which case all the values are shown $\left({ }^{b}\right)$.

The protection study showed that the aMPV/B vaccine provided a complete virological protection against aMPV/A, whereas positive samples were detected in some vaccinated chicks challenged with the aMPV/B isolate.

\section{DISCUSSION}

After the first detection of aMPV in Brazil (Arns \& Hafez 1995), massive vaccination was established in commercial flocks. However, recent studies showed that aMPV/A and aMPV/B are still circulating in Brazil, affecting broilers, breeders, laying hens and turkeys (D'Arce et al. 2005, Chacón et al. 2007,2011), with a majority of aMPV/B detected. In addition, Villarreal (2009) showed that subpopulations of aMPV/B are present in Brazil and suggested that escape mutants could emerge from the vaccines due to an insufficient protection. Finally, both studies revealed that the aMPV/B vaccine strain used in the country and the Brazilian aMPV/B field strains are grouped in separated clusters (Villarreal et al. 2009, Chacón et al. 2011). Subtype B also predominates in Israel and in six countries of Western Europe (Banet-Noach et al. 2005, Jones, 2010) and, according to the authors, this situation perhaps reflects the efficacy and wider use of subtype B vaccines (as a result of acquiring mutations by the vaccine strain). In order to investigate the protective response induced by an aMPV/B vaccine against Brazilian isolates, this study was conducted into two parts.

In the first part, two aMPV isolates (A and B subtypes) of chicken origin were characterized and were shown to be able to replicate efficiently in vivo, although they had different patterns of replication and clinico-pathological effects. Both viruses could be detected mainly in sinuses, whereas aMPV/ B also replicated in trachea at low Ct values. In addition, aMPV/B could be detected during a longer period and in significantly higher quantities compared to aMPV/A field strain. In a parallel study performed by our group, similar or lower quantities were detected in trachea and sinusal samples at 5 d.p.i. after infection with four different aMPV/A isolates in two weeks old chicks (data not shown). Although another comparative study in turkeys did not indicate differences between aMPV/A and aMPV/B 
concerning respiratory signs (Van de Zande et al. 1999), similar observations of differences in virulence between these subtypes were found in ducklings, turkeys, and broilers (Toquin et al. 2006, Aung et al. 2008). Thus, our data indicates differences in replication ability and virulence of type $\mathrm{A}$ and $\mathrm{B}$ aMPV in chicks.

We also investigated the protection conferred by a commercial aMPV/B vaccine against Brazilian aMPV field strains of A and B subtypes. Our results demonstrate that a complete heterologous protection was conferred by the aMPV/B vaccine. This was expected as the aMPV/A replicated less efficiently than aMPV/B isolate. Interestingly, a partial protection was observed in some birds after vaccination with the aMPV/B vaccine and challenge with Brazilian aMPV/B isolate, despite the high SN titres developed after vaccination. Although the presence of antibodies to aMPV has been shown to have little effect on the fate of virus in the respiratory tract (Jones et al. 1992), antibodies are reliable indicators of vaccine immunogenicity' (Jones 1996).

Two recent field studies, carried out in Israel and Italy, reported a lack of complete homologous protection due to genetic divergence between aMPV/B field and vaccine strains. These studies suggested that the field virus was able to overcome the immunity induced by the vaccine, due to aminocid differences between the vaccine and field strains in the SH and G gene products, respectively (Banet-Noach et al. 2009, Catelli et al. 2010). A similar situation is found in Brazil, where aMPV/B vaccine strain used in the country forms a monophyletic group different from the Brazilian aMPV/B isolates (Chacón, et. Al. 2011, Villarreal et al. 2009), witch could be an explanation for the partial homologous protection observed in some birds of our study.

Regardless, it should be considered that aMPV/B was not detected in all vaccinated/challenged birds and infectious virus was detected only in one bird. Similarly, Ganapathy (2007) showed that an aMPV/B vaccine was effective against clinical signs in chicks, although one bird was positive by RT-PCR or virus isolation.

\section{CONLUSIONS}

In summary, the present study showed that the Brazilian aMPV/B isolate displays a higher replication ability in chickens than the isolate aMPV/A. Furthermore, the aMPV/B vaccine provided a complete heterologous virological protection, although homologous protection was not complete.

Despite the low number of aMPV/B positive birds detected after homologous challenge, it should be considered that field viruses can replicate in vaccinated birds and contaminate the environment allowing the emergence of escape mutants.

Therefore, a continuous surveillance is required to detect changes in the circulation of aMPV/A and aMPV/B or introduction of new viral subtypes.

\section{REFERENCES}

Alvarez R.L., Kapczynski D.R., Njenga M.K. \& Seal B.S. 2003. Nucleotide and predicted amino acid sequence-based analysis of the avian metapneu- movirus type $\mathrm{C}$ cell attachment glycoprotein gene: phylogenetic analysis and molecular epidemiology of U.S. pneumoviruses. J. Clin. Microbiol. 41:1730-1735.

Arns C.W. \& Hafez H.M. 1995. Isolation and identification of Avian Pneumovirus from broiler breeder flocks in Brazil, p.124-125. In: Jensen M.M. (Ed.), Proceedings of the $44^{\text {th }}$ Western Poultry Diseases Conference, Sacramento, California.

Aung Y.H., Liman M., Neumann U. \& Rautenschlein S. 2008. Reproducibility of swollen sinuses in broilers by experimental infection with avian metapneumovirus subtypes A and B of turkey origin and their comparative pathogenesis. Avian Pathol. 37:65-74.

Banet-Noach C., Simanov L. \& Perk S. 2005. Characterization of Israeli avian metapneumovirus strains in turkeys and chickens. Avian Pathol. 34:220-226.

Banet-Noach C., Simanov L., Laham-Karam N., Perk S. \& Bacharach E. 2009. Longitudinal survey of avian metapneumoviruses in poultry in Israel: infiltration of field strains into vaccinated flocks. Avian Dis. 53:184-189.

Catelli E., Cecchinato M., Savage C.E., Jones R.C. \& Naylor C.J. 2006. Demonstration of loss of attenuation and extended field persistence of a live avian metapneumovirus vaccine. Vaccine 24:6476-82.

Catelli E., Lupini C., Cecchinato M., Ricchizzi E., Brown P. \& Naylor C.J. 2010. Field avian metapneumovirus evolution avoiding vaccine induced immunity. Vaccine 28:916-921.

Chacón J.L., Brandão P.E., Buim M., Villarreal L. \& Ferreira A.J. 2007. Detection by reverse transcriptase-polymerase chain reaction and molecular characterization of subtype B avian metapneumovirus isolated in Brazil. Avian Pathol. 36:383-387.

Chacón J.L., Mizuma M., Vejarano M.P., Toquín D., Eterradossi N., Patnayak D.P., Goyal S.M. \& Ferreira A.J. 2011. Avian metapneumovirus subtypes circulating in Brazilian vaccinated and non-vaccinated chicken and turkey farms. Avian Dis. 55(1):82-89.

Cecchinato M., Catelli E., Lupini C., Ricchizzi E., Clubbe J. \& Naylor C.J. 2009. Evidence of aMPV attachment protein evolution coincident with mass live vaccine introduction in Italy. Proceedings VI International Symposium on Avian Corona- and Pneumoviruses and Complicating Pathogens, Rauischholzhausen, Germany, p.278-284.

Cook J.K.A., Huggins M.B., Wood M.A., Orbell S.J. \& Mockett A.P.A. 1995. Protection provided by a commercially available vaccine against different strains of turkey rhinotracheitis virus. Vet. Rec. 136:392-393.

Cook J.K. 2000. Avian pneumovirus infections of turkeys and chickens. Vet. Journal 160:118-125.

Coswig L.T., Santos M.B., Hafez M.H., Ferreira H.F. \& Arns C.W. 2010. Propagation of avian metapneumovirus subtypes A and B using chicken embryo related and other cell systems. J. Virol. Methods 167:1-4.

Dar A.M.T.K., Munir S., Panigrahy B., Goyal S.M. \& Kapur V. 2001. PCR-based detection of an emerging avian pneumovirus in US turkey flocks. J. Vet. Diagn. Invest. 13:201-205.

D’Arce R.C., Coswig L.T., Almeida R.S., Trevisol I.M., Monteiro M.C., Rossini L.I., Di Fabio J., Hafez H.M. \& Arns C.W. 2005. Subtyping of new Brazilian avian metapneumovirus isolates from chickens and turkeys by reverse transcriptase-nested-polymerase chain reaction. Avian Pathol. 34:133-136.

Eterradossi N., Toquin D., Guittet M. \& Bennejean G. 1995. Evaluation of different turkey rhinotracheitis viruses used as antigens for serological testing following live vaccination and challenge. J. Vet. Medicine 42:175186.

Ferreira H.L., Spilki F.R., Santos M.B., Almeida R.S. \& Arns C.W. 2009. Comparative evaluation of conventional RT-PCR and real-time RT-PCR (RRT-PCR) for detection of avian metapneumovirus subtype A. Ciência Rural 39:1445-1451.

Ganapathy K. \& Jones R.C. 2007. Vaccination of chicks with live attenuated subtype B avian metapneumovirus vaccines: protection against challenge and immune responses can be unrelated to vaccine dose. Avian Dis. 51:733-737.

Gough R.E. \& Jones R.C. 2008. Avian metapneumovirus, p.101-110. In: Saif Y.M., Barnes H.J., Glisson J.R., Fadly A.M., McDougald L.R. \& Swayne D.E. (Eds), Diseases of Poultry. $12^{\text {th }}$ ed. Iowa State Press, Ames. 
Jirjis F.F., Noll S.L., Halvorson D.A., Nagaraja K.V. \& Shaw D.P. 2009. Pathogenesis of avian pneumovirus infection in turkeys. Vet. Pathol. 39:300-310.

Jones R.C. 2010. Viral respiratory diseases (ILT, aMPV infections, IB): Are they ever under control? Brit. Poult. Sci. 51(1):1-11. (Review)

Naylor C., Shaw K., Britton P. \& Cavanagh D. 1997. Appearance of type B avian pneumovirus in great Britain. Avian Pathol. 26(2):327-338.

Juhasz K. \& Easton A.J. 1994. Extensive sequence variation in the attachment $(\mathrm{G})$ protein gene of avian pneumovirus: evidence for two distinct subgroups. J. General Virol. 75:2873-2880.

Jones R.C., Naylor C.J., Al-Afaleq A., Worthington K.J. \& Jones R. 1992. Effect of cyclophosphamide immunosuppression on the immunity of turkeys to viral rhinotracheitis. Res. Vet. Sci. 53:38-41.

Jones R.C. 1996. Avian pneumovirus infection: Questions still unanswered. Avian Pathol. 25:639-648.

Njenga M.K., Lwamba H.M. \& Seal B.S. 2003. Metapneumoviruses in birds and humans. Virus Res. 91:163-169.

Reed J. \& Muench H. 1938. A simple method for estimating fifty percent end points. Am. J. Hygiene 27:49.

Ricchizzi E., Catelli E., Cecchinato M., Lupini C., Brown P. \& Naylor C.J. 2009. Turkey rhinotracheitis outbreak in 7- week-old turkeys caused by a vaccine derived avian metapneumovirus. Proceedings VI International Symposium on Avian Corona- and Pneumoviruses and Complicating Pathogens, Rauischholzhausen, Germany, p.260-264.
Santos M.B. 2010. Experimental studies with avian metapneumovirus (aMPV) subtypes A and B isolates in broiler chickens. Dissertação de Doutorado em Genética e Biologia Molecular, Universidade Estadual de Campinas, Campinas, SP, Brazil. 32p.

Toquin D., Bäyon-Auboyer M.H., Senne D.A. \& Eterradossi N. 2000. Lack of antigenic relationship between French and recent North American non-A/non-B turkey rhinotracheitis viruses. Avian Dis. 44:977-982.

Toquin D., Guionie O., Jestin V., Zwingelstein F., Allee C. \& Eterradossi N. 2006. European and American subgroup $C$ isolates of avian metapneumovirus belong to different genetic lineages. Virus Genes 32:97-103.

Van De Zande S., Nauwynck H., Cavanagh D. \& Pensaert M. 1998. Infection and reinfection with Avian Pneumovirus subtype A and B on Belgian turkey farms and relation to respiratory problems. J. Vet. Medicine 45:621-626.

Villarreal L.Y., Brandão P.E., Chacón J.L., Assayag M.S., Maiorka P.C., Raffi P., Saidenberg A.B., Jones R.C. \& Ferreira A.J. 2007. Orchitis in roosters with reduced fertility associated with avian infectious bronchitis virus and avian metapneumovirus infections. Avian Dis. 51(4):900-904.

Villarreal L.Y.B., Sandri T.L., Assayag L.J., Richtzenhain L.J., Malo A. \& Brandão P.E. 2009. Field observations after natural infection of Brazilian layer chickens with a phylogenetically divergent lineage of subtype B aMPV. Proc. VI International Symposium on Avian Corona- and Pneumoviruses and Complicating Pathogens, Rauischholzhausen, Germany, p.255-259. 